\title{
Feeding ecology of the swordfish Xiphias gladius in the subtropical region and transition zone of the western North Pacific
}

\author{
Hikaru Watanabe ${ }^{1, *}$, Tsunemi Kubodera $^{2}$, Kotaro Yokawa $^{3}$ \\ ${ }^{1}$ National Research Institute of Far Seas Fisheries (Yokohama), 2-12-4 Fukuura Kanazawa Yokohama, \\ Kanagawa 236-8648, Japan \\ ${ }^{2}$ National Science Museum, 3-23-1 Hyakunin-cho Shinjyuku, Tokyo 169-0073, Japan \\ ${ }^{3}$ National Research Institute of Far Seas Fisheries (Shimizu), 1-15-1 Orido Shimizu, Shizuoka 424-8633, Japan
}

\begin{abstract}
This is the first time a quantitative analysis has been carried out on feeding habits of swordfish Xiphias gladius $(\mathrm{n}=455)$, mainly ranging from 1200 to $2100 \mathrm{~mm}$ in eye-fork length, in the western North Pacific. Based on these data, we examined the feeding ecology of this species in relation to its seasonal south-north migration between subtropical and transition waters. The main $X$. gladius prey size was 80 to $500 \mathrm{~mm}$, and the size spectrum of the prey shifted to a smaller range from spring to summer. In winter and spring, $X$. gladius was distributed in the subtropical region and fed mainly on the winter-spring cohort of neon flying squid Ommastrephes bartramii, followed by Pacific pomfret Brama japonica. In summer and autumn, X. gladius migrated to the transition zone between the Kuroshio front and subarctic boundary and fed mainly on the winter-spring cohort of $O$. bartramii, which also migrates into the transition zone from the subtropical region in summer. Other common prey species in summer and autumn were the gonatid squid Gonatopsis borealis and the myctophid fish Diaphus gigas, which are endemic to transition and/or subarctic regions. B. japonica almost disappeared from the stomachs of $X$. gladius during these seasons because this species migrates in summer into the subarctic region, north of the range of $X$. gladius. Therefore, seasonal changes in stomach contents of $X$. gladius could be explained by the difference in seasonal south-north migration patterns between predator and prey. The seasonal south-north migration of $X$. gladius seems to be a feeding migration, following the migration of the winter-spring cohort of $O$. bartramii.
\end{abstract}

KEY WORDS: Xiphias gladius · Feeding habits - Ommastrephes bartramii - Seasonal migration · Subtropical and transition waters $\cdot$ Western North Pacific

\section{INTRODUCTION}

The swordfish Xiphias gladius is among the largest pelagic fish, reaching 2500 to $3000 \mathrm{~mm}$ in eye-fork length (EFL). The species occurs worldwide from tropical to transition waters (Sakagawa \& Bell 1980, Nakamura 1985). The main habitat of this fish in the western North Pacific is the subtropical region, which consists of the subtropical frontal zone north of the subtropical front, the subtropical domain to the south, and the transition zone between the Kuroshio front and the subarctic boundary (Favorite et al. 1976, Pearcy 1991, Roden 1991; Fig. 1). X. gladius migrates northward from the subtropical region to the transition zone dur- ing spring and summer, and southward during autumn and winter for reproduction (Polovina et al. 2000, Seki et al. 2002, Takahashi et al. 2003). Previous studies have indicated that $X$. gladius feeds mainly on large squid and finned fish, suggesting that this species plays an important role as a top predator in high-sea ecosystems (Scott \& Tibbo 1968, Stillwell \& Kohler 1985, Pearcy 1991, Hernandez-Garcia 1995). Although considerable knowledge has been accumulated pertaining to the feeding habits of $X$. gladius in the North Atlantic and the eastern North Pacific (Scott \& Tibbo 1968, Toll \& Hess 1981, Stillwell \& Kohler 1985, Moreira 1990, Markaida \& Sosa-Nishizaki 1998), such information is extremely restricted in the western 


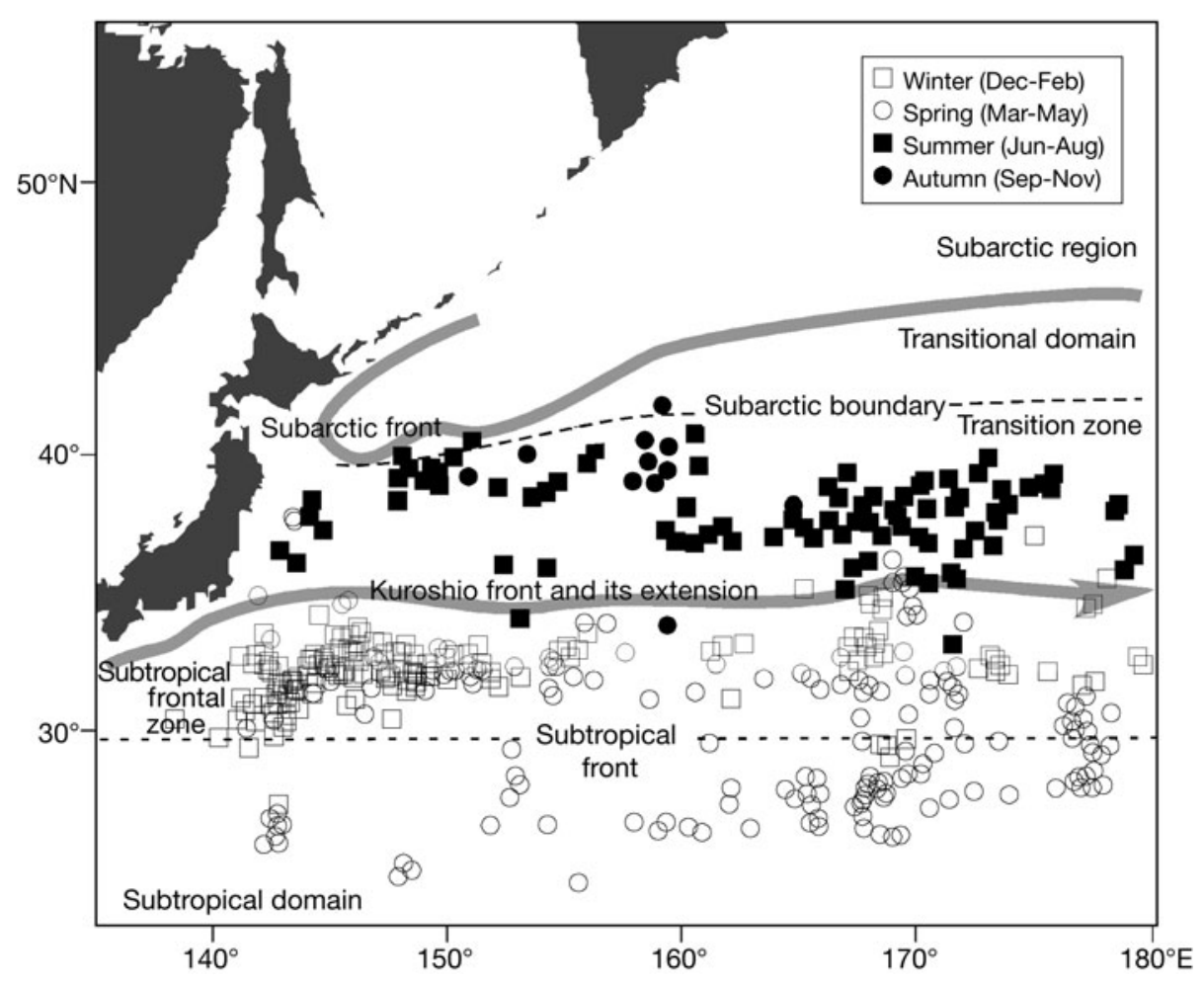

Fig. 1. Sampling localities in each season in the western North Pacific

North Pacific, especially in the subtropical and transition regions (Moteki et al. 2001). These data are essential not only for estimating the feeding strategy of swordfish in this region, but also for establishing new methods for the sustainable exploitation of this important fisheries resource based on ecosystemic information, which is recognized worldwide as an important management approach for future fisheries (World Summit on Sustainable Development 2002, Garcia \& Zerbi 2003). Several projects under the North Pacific Marine Science Organization (PICES) and Global Ocean Ecosystem Dynamics (GLOBEC) are ongoing in the North Pacific in relation to the development of such ecosystem approaches to fisheries.

We aimed to quantitatively examine the feeding habits of Xiphias gladius in the subtropical and transition waters of the western North Pacific during each season, and to determine their feeding strategies in relation to their south-north migrations and diel vertical migrations.

\section{MATERIALS AND METHODS}

Samples were taken from both the subtropical region and transition zone during June 1996, MarchJuly 2000, March-December 2001, February-July and December 2002, and January-April 2003 in the west- ern North Pacific (Table 1). Sampling localities corresponded well with the distribution centers of Xiphias gladius in each season (see 'Discussion'), and generally shifted northward in summer and autumn due to summertime migrations of the fish (Fig. 1). All X. gladius were collected by commercial swordfish fishing vessels using long lines in the 0-100 m layer, which corresponds with the main habitat depth of $X$. gladius at night. Long lines were deployed at dusk and

Table 1. Xiphias gladius. Numbers of swordfish collected in each year and month

\begin{tabular}{|c|c|c|c|c|c|c|}
\hline \multirow{2}{*}{ Month } & \multicolumn{5}{|c|}{-Year- } & \multirow{2}{*}{ Total } \\
\hline & 1996 & 2000 & 2001 & 2002 & 2003 & \\
\hline 1 & 0 & 0 & 0 & 0 & 59 & 59 \\
\hline 2 & 0 & 0 & 0 & 4 & 46 & 50 \\
\hline 3 & 0 & 12 & 5 & 17 & 52 & 86 \\
\hline 4 & 0 & 35 & 6 & 14 & 15 & 70 \\
\hline 5 & 0 & 17 & 20 & 16 & 0 & 53 \\
\hline 6 & 6 & 2 & 31 & 5 & 0 & 44 \\
\hline 7 & 0 & 1 & 48 & 2 & 0 & 51 \\
\hline 8 & 0 & 0 & 11 & 0 & 0 & 11 \\
\hline 9 & 0 & 0 & 8 & 0 & 0 & 8 \\
\hline 10 & 0 & 0 & 1 & 0 & 0 & 1 \\
\hline 11 & 0 & 0 & 3 & 0 & 0 & 3 \\
\hline 12 & 0 & 0 & 7 & 12 & 0 & 19 \\
\hline Total & 6 & 67 & 140 & 70 & 172 & 455 \\
\hline
\end{tabular}


retrieved before dawn on the following day. During each sampling period, sea surface temperature (SST) was measured. Aboard the ship, swordfish wet body weights (BW) were measured and stomachs were removed. Stomachs were frozen at $-30^{\circ} \mathrm{C}$ for further analysis in the laboratory ashore. We estimated EFL $(\mathrm{cm})$ of each individual from the BW $(\mathrm{kg})$ values using the following equations obtained in this study area in each season (K. Yokawa unpubl. data):

Winter (Dec to Feb): BW $=\mathrm{e}^{-12.1389} \times \mathrm{EFL}^{3.2231}$

Spring (Mar to May): BW $=\mathrm{e}^{-12.4565} \times \mathrm{EFL}^{3.2915}$

Summer (Jun to Aug): BW $=\mathrm{e}^{-11.6042} \times \mathrm{EFL}^{3.1003}$

Autumn (Sep to Nov): BW $=\mathrm{e}^{-10.7864} \times \mathrm{EFL}^{2.9558}$

In total, 455 individuals were examined for stomach content analysis. We excluded all fresh and minimally digested Japanese common squid Todarodes pacificus, mackerel Scomber spp., and Jack mackerel Trachurus japonicus from the stomach content analysis to avoid contamination of the samples with long line bait. Zooplankton prey items were counted and identified to the lowest taxonomic level possible, and wet weights of each taxon were measured. All fresh and minimally digested cephalopod and fish prey were identified to the lowest taxonomic level possible, and their body length (dorsal mantle length, DML, for cephalopods and standard length, SL, for fish) and wet wt were recorded. Heavily digested cephalopod and fish prey items were identified based on the morphology of their lower beaks and sagittal otoliths, respectively. For these items, the rostral lengths of the lower beaks of cephalopods and the maximum diameters of sagittal fish otoliths were also measured to estimate the original body sizes and wet weights of the prey, using relationships generated from intact specimens of the main prey species (Kubodera 1982, Clarke 1986, Kubodera \& Furuhashi 1987, Kubodera \& Shimazaki 1989, Smale et al. 1995, Ohizumi et al. 2001, T. Kubodera \& H. Watanabe unpubl. data). These relationships could not be obtained for some minor prey species, such as the octopus Japetella diaphana and gonostomatid fishes like Gonostoma elongatum. For these species, the original wet weights were estimated based on values for similar-sized individuals or values for only slightly digested specimens of each species. The number of eaten fish was estimated as the maximum number of right or left fish otoliths.

The stomach content index (SCI) was calculated as:

SCI $(\%)=$ (wet wt of stomach contents including both fresh and digested items/BW excluding wet wt of stomach contents) $\times 100$
We calculated the proportion of each prey item among the total number of food items identified $(N)$, the wet wt contribution of each food item to the total wet wt of the stomach contents $(W)$, and the frequency of the occurrence $(F)$ of each food item in the total number of stomachs examined. Using these 3 indices, an index of the relative importance (IRI; Pinkas et al. 1971) of each food item $i$ was calculated using the equation:

$$
\mathrm{IRI} i=(\mathrm{Ni}+\mathrm{Wi}) \times \mathrm{Fi}
$$

This index is represented by the size of the rectangle resolved by plotting the 3 values on a 3-way graph. To readily allow comparison among prey items, the IRI was standardized to \%IRI for each prey item (Cortes 1997).

\section{RESULTS}

\section{Habitat, SST, and size composition}

Sea surface water temperatures in which Xiphias gladius were generally captured were $17-20^{\circ} \mathrm{C}$ in winter, spring, and autumn, and $17-21^{\circ} \mathrm{C}$ in summer, suggesting that $X$. gladius were distributed mainly in areas with similar SSTs in all seasons (Fig. 2a). EFL size-frequency distributions showed a clear mode between 1200 and $2000 \mathrm{~mm}$ from winter to summer, representing 4 to 7 year old individuals (Sun et al. 2002; Fig. 2b). In autumn, these modes were not found due to the small sample size, but the size range of captured individuals was 1200 to $2100 \mathrm{~mm}$ EFL, which was similar to the main size range of the fish collected in other seasons. Therefore, the age composition of the present $X$. gladius sample may have been similar throughout the seasons.

\section{Diet composition}

We identified 70 prey species belonging to 57 genera in the 455 examined stomachs (Table 2). Of these stomachs, $21(4.6 \%)$ were empty. The following results indicate that Ommastrephes bartramii was one of the most common prey species regardless of season (Table 3).

\section{Subtropical region in winter}

The most common prey species was Ommastrephes bartramii, with $N, W$, and $F$ values of 28.0, 61.8, and $57.8 \%$, respectively, followed by Pacific pomfret Brama japonica $(9.7,13.8$, and $40.6 \%)$. In terms of $W$, B. japonica and diamondback squid Thysanoteuthis 
(a) Percent occurrence in relation to SST
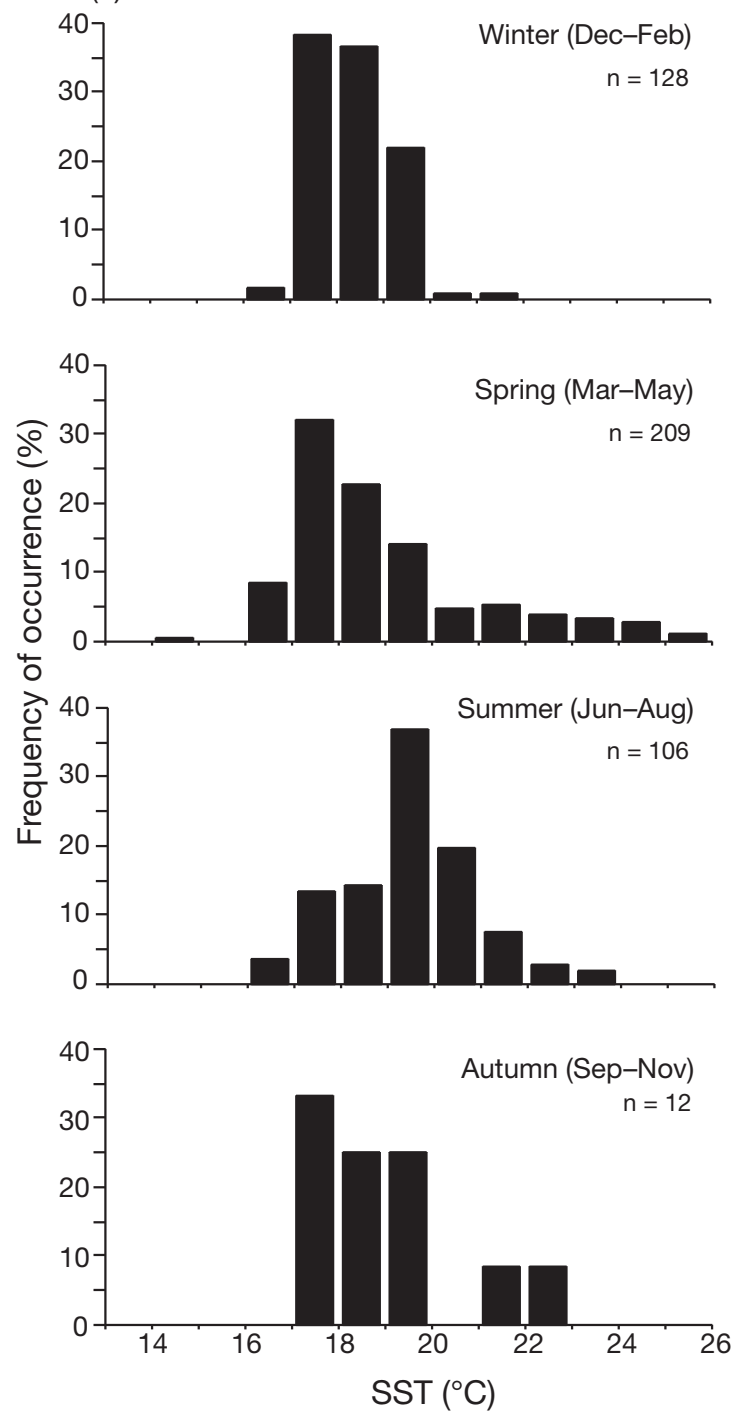

(b) Size distributions
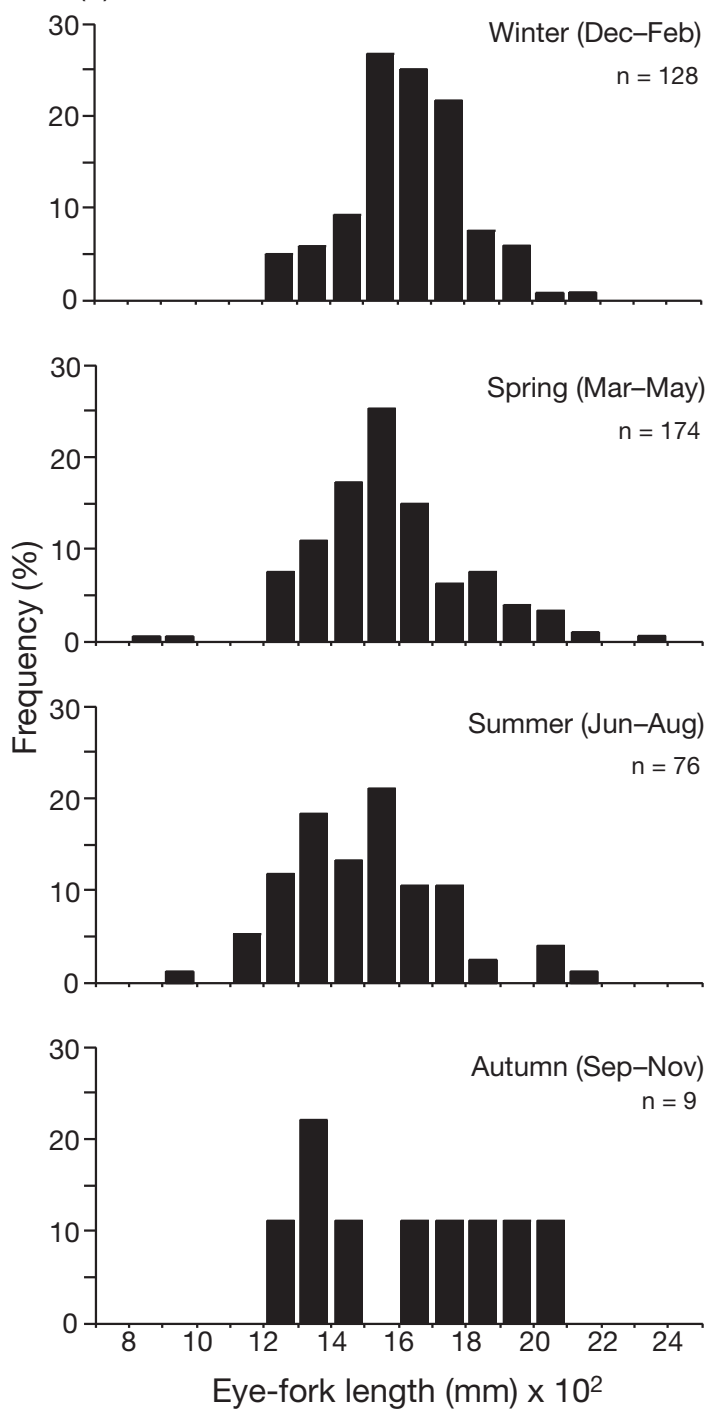

Fig. 2. Xiphias gladius. (a) Percent occurrence of the total number of samples in relation to sea surface water temperature (SST) in each season. (b) Size distributions in each season. n: number of individuals captured

rhombus $(13.0 \%)$ were equally important. However, both $N(1.6 \%)$ and $F(7.0 \%)$ values of $T$. rhombus were much lower than those of $B$. japonica. As a result, the \%IRI of $O$. bartramii (78.6\%) was the highest, followed by $B$. japonica $(14.5 \%)$, while values of other species were $<2.0 \%$. These results suggest that Xiphias gladius preyed mainly on $O$. bartramii and secondarily on B. japonica.

\section{Subtropical region in spring}

Ommastrephes bartramii was the most common species in the stomachs, with $N, W$, and $F$ values of 30.1, 61.8 , and $45.5 \%$, respectively, followed by Brama japonica $(8.8,18.2$, and $22.5 \%)$. The \%IRI values of $O$. bartramii and B. japonica were 84.4 and $12.3 \%$, respectively, whereas those of other species were $<1.0 \%$. These results suggest that in the subtropical region, the main prey species were the same in winter and spring.

\section{Transition zone in summer}

The subarctic gonatid squid Gonatopsis borealis was the most common prey by $N(13.5 \%), W(28.4 \%), F$ $(46.4 \%)$, and \%IRI (46.4) values. In terms of $W$ and $F$ values, Ommastrephes bartramii ranked as the second $(22.6 \%)$ and third $(30.2 \%)$ most important prey, 


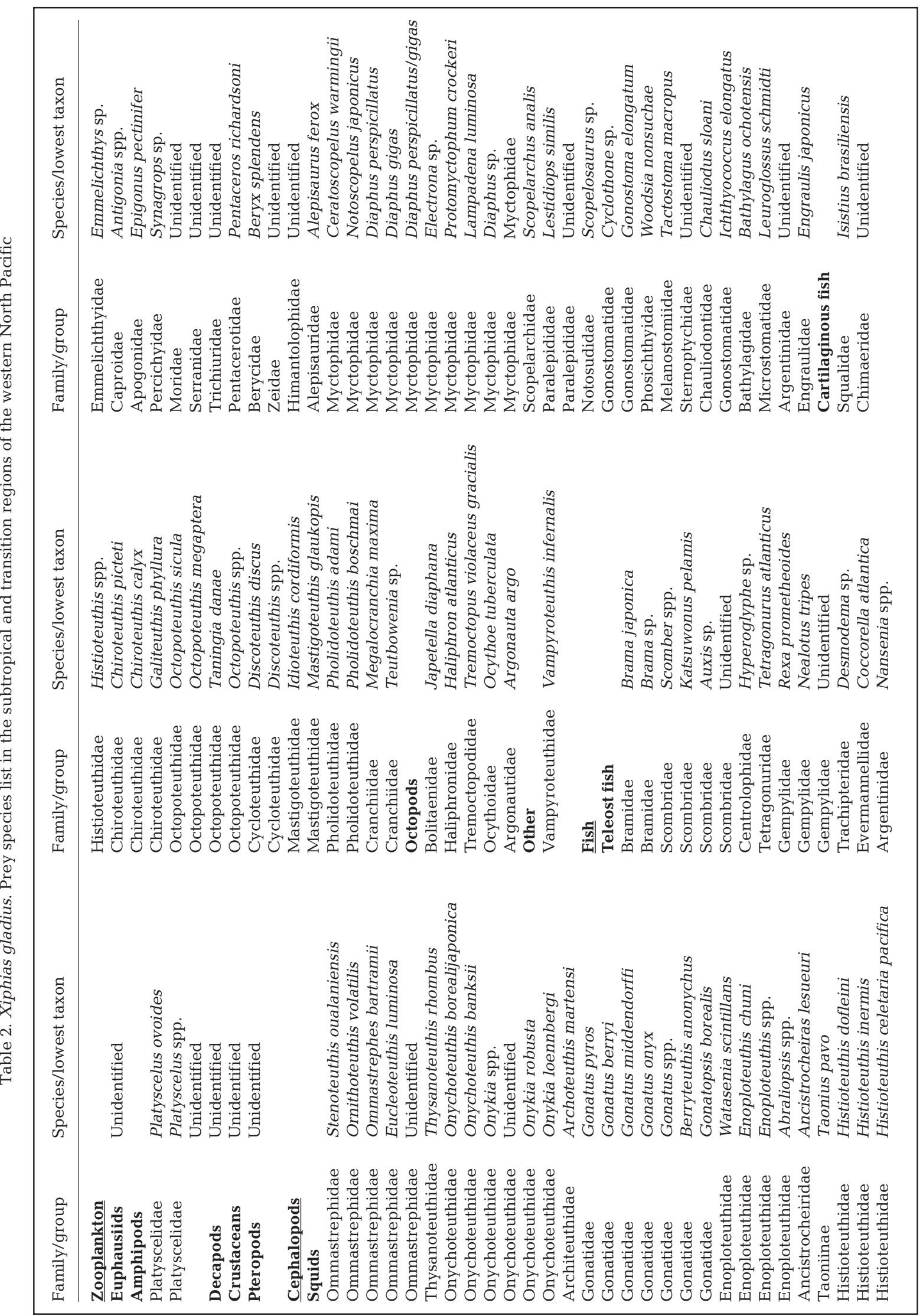


Table 3. Xiphias gladius. The 15 most important prey species in terms of \% index of relative importance (\%IRI, see 'Materials and methods' for details) in each season. Prey species composition by abundance $(N, \%)$ and wet wt $(W, \%)$, and frequency of occurrence $(F, \%)$ of each prey in the total number of stomachs examined are also depicted. CR: crustacean zooplankton; SQ: squid; OC: octopus; TF: teleost fish

\begin{tabular}{|c|c|c|c|c|c|c|c|c|c|c|c|c|c|}
\hline $\begin{array}{l}\text { Rank } \\
\text { of } \\
\text { IRI }\end{array}$ & $\begin{array}{l}\text { Prey } \\
\text { cate- } \\
\text { gory }\end{array}$ & Species & $\begin{array}{c}N \\
(\%)\end{array}$ & $\begin{array}{c}W \\
(\%)\end{array}$ & $\begin{array}{c}F \\
(\%)\end{array}$ & $\begin{array}{l}\text { IRI } \\
(\%)\end{array}$ & $\begin{array}{l}\text { Rank } \\
\text { of } \\
\text { IRI }\end{array}$ & $\begin{array}{l}\text { Prey } \\
\text { cate- } \\
\text { gory }\end{array}$ & Species & $\begin{array}{c}N \\
(\%)\end{array}$ & $\begin{array}{c}W \\
(\%)\end{array}$ & $\begin{array}{c}F \\
(\%)\end{array}$ & $\begin{array}{l}\text { IRI } \\
(\%)\end{array}$ \\
\hline \multicolumn{7}{|c|}{ Winter (Dec-Feb) } & \multicolumn{7}{|c|}{ Summer (Jun-Aug) } \\
\hline 1 & $\mathrm{SQ}$ & Ommastrephes bartramii & 28.0 & 61.8 & 57.8 & 78.6 & 1 & $\mathrm{SQ}$ & Gonatopsis borealis & 13.5 & 28.4 & 43.4 & 46.4 \\
\hline 2 & TF & Brama japonica & 9.7 & 13.8 & 40.6 & 14.5 & 2 & $\mathrm{SQ}$ & Ommastrephes bartramii & 6.4 & 22.6 & 30.2 & 22.3 \\
\hline 3 & $\mathrm{SQ}$ & Moroteuthis loennbergi & 5.1 & 1.9 & 17.2 & 1.8 & 3 & $\mathrm{TF}$ & Diaphus gigas & 11.9 & 2.7 & 36.8 & 13.7 \\
\hline 4 & $\mathrm{SQ}$ & Thysanoteuthis rhombus & 1.6 & 13.0 & 7.0 & 1.6 & 4 & $\mathrm{SQ}$ & Onychoteuthis banksii & 7.5 & 2.3 & 11.3 & 2.8 \\
\hline 5 & $\mathrm{SQ}$ & Stenoteuthis oualaniensis & 3.9 & 2.1 & 10.9 & 1.0 & 5 & TF & Brama japonica & 1.7 & 5.0 & 14.2 & 2.4 \\
\hline 6 & $\mathrm{SQ}$ & Onychoteuthis borealijaponica & 3.7 & 0.2 & 14.1 & 0.8 & 6 & $\mathrm{TF}$ & Paralepididae & 5.9 & 0.2 & 14.2 & 2.2 \\
\hline 7 & TF & Diaphus perspicillatus/gigas & 13.6 & 0.2 & 3.9 & 0.8 & 7 & TF & Alepisaurus ferox & 0.8 & 10.4 & 6.6 & 1.9 \\
\hline 8 & $\mathrm{SQ}$ & Eucleoteuthis luminosa & 1.2 & 0.4 & 5.5 & 0.1 & 8 & $\mathrm{SQ}$ & Eucleoteuthis luminosa & 3.0 & 2.8 & 12.3 & 1.8 \\
\hline 9 & $\mathrm{SQ}$ & Taningia danae & 0.4 & 2.8 & 2.3 & 0.1 & 9 & SQ & Gonatus spp. & 4.0 & 1.0 & 12.3 & 1.5 \\
\hline 10 & TF & Alepisaurus ferox & 0.9 & 0.8 & 3.9 & 0.1 & 10 & $\mathrm{SQ}$ & Onykia loennbergi & 1.8 & 4.0 & 4.7 & 0.7 \\
\hline 11 & $\mathrm{CR}$ & Amphipods & 2.4 & 0.0 & 2.3 & 0.1 & 11 & $\mathrm{SQ}$ & Gonatus berryi & 2.6 & 0.0 & 10.4 & 0.7 \\
\hline 12 & $\mathrm{SQ}$ & Enoploteuthis spp. & 1.3 & 0.0 & 3.9 & 0.1 & 12 & $\mathrm{SQ}$ & Stenoteuthis oualaniensis & 0.3 & 7.1 & 2.8 & 0.5 \\
\hline 13 & $\mathrm{TF}$ & Paralepididae & 1.0 & 0.0 & 3.9 & 0.1 & 13 & SQ & Onychoteuthis borealijaponica & 1.8 & 0.4 & 9.4 & 0.5 \\
\hline 14 & $\mathrm{SQ}$ & Histioteuthis dofleini & 1.0 & 0.4 & 2.3 & $<0.1$ & 14 & $\mathrm{SQ}$ & Gonatus pyros & 1.5 & 0.1 & 8.5 & 0.3 \\
\hline 15 & $\mathrm{TF}$ & $\begin{array}{l}\text { Trichiuridae } \\
\text { Total no. inds: } 669 \\
\text { Total wet wt (g): } 450628.5\end{array}$ & 0.7 & 1.0 & 1.6 & $<0.1$ & 15 & $\mathrm{TF}$ & $\begin{array}{l}\text { Nansenia spp. } \\
\text { Total no. inds: } 1426 \\
\text { Total wet wt (g): } 138486.5\end{array}$ & 1.4 & 0.2 & 4.7 & 0.2 \\
\hline \multicolumn{7}{|c|}{ Spring (Mar-May) } & \multicolumn{7}{|c|}{ Autumn (Sep-Nov) } \\
\hline 1 & $\mathrm{SQ}$ & Ommastrephes bartramii & 30.1 & 61.8 & 45.5 & 84.4 & 1 & $\mathrm{SQ}$ & Ommastrephes bartramii & 20.4 & 38.0 & 33.3 & 42.0 \\
\hline 2 & $\mathrm{TF}$ & Brama japonica & 8.8 & 18.2 & 22.5 & 12.3 & 2 & $\mathrm{SQ}$ & Gonatopsis borealis & 13.3 & 13.8 & 41.7 & 24.3 \\
\hline 3 & $\mathrm{SQ}$ & Onychoteuthis borealijaponica & 3.8 & 0.6 & 10.0 & 0.9 & 3 & $\mathrm{TF}$ & Diaphus gigas & 9.2 & 1.1 & 50.0 & 11.1 \\
\hline 4 & $\mathrm{SQ}$ & Thysanoteuthis rhombus & 0.8 & 9.3 & 3.3 & 0.7 & 4 & SQ & Eucleoteuthis luminosa & 7.1 & 4.9 & 16.7 & 4.3 \\
\hline 5 & $\mathrm{SQ}$ & Moroteuthis loennbergi & 2.2 & 1.0 & 5.3 & 0.3 & 5 & $\mathrm{SQ}$ & Paralepidodae & 7.1 & 0.1 & 25.0 & 3.9 \\
\hline 6 & $\mathrm{SQ}$ & Enoploteuthis chuni & 1.7 & 0.1 & 7.2 & 0.3 & 6 & $\mathrm{TF}$ & Gonatus middendorffi & 7.1 & 1.5 & 16.7 & 3.1 \\
\hline 7 & $\mathrm{TF}$ & Diaphus gigas & 4.3 & 0.2 & 2.4 & 0.2 & 7 & SQ & Onykia robusta & 1.0 & 13.6 & 8.3 & 2.6 \\
\hline 8 & $\mathrm{TF}$ & Alepisaurus ferox & 0.8 & 0.7 & 2.4 & 0.1 & 8 & $\mathrm{TF}$ & Desmodema sp. & 1.0 & 13.1 & 8.3 & 2.5 \\
\hline 9 & $\mathrm{SQ}$ & Histioteuthis inermis & 1.2 & 0.5 & 1.9 & 0.1 & 9 & $\mathrm{SQ}$ & Histioteuthis dofleini & 2.0 & 2.8 & 16.7 & 1.8 \\
\hline 10 & $\mathrm{SQ}$ & Stenoteuthis oualaniensis & 0.8 & 0.3 & 2.9 & 0.1 & 10 & $\mathrm{TF}$ & Brama japonica & 1.0 & 6.3 & 8.3 & 1.3 \\
\hline 11 & $\mathrm{TF}$ & Katsuwonus pelamis & 0.6 & 1.5 & 1.4 & 0.1 & 11 & $\mathrm{TF}$ & Nansenia spp. & 2.0 & 0.2 & 16.7 & 0.8 \\
\hline 12 & $\mathrm{SQ}$ & Eucleoteuthis luminosa & 0.7 & 0.2 & 2.4 & $<0.1$ & 12 & $\mathrm{SQ}$ & Gonatus onyx & 1.0 & 2.9 & 8.3 & 0.7 \\
\hline 13 & OC & Haliphron atlanticus & 1.4 & 0.0 & 1.4 & $<0.1$ & 13 & $\mathrm{SQ}$ & Chiroteuthis calyx & 1.0 & 1.0 & 8.3 & 0.4 \\
\hline 14 & $\mathrm{TF}$ & Paralepididae & 0.8 & 0.0 & 2.4 & $<0.1$ & 14 & $\mathrm{SQ}$ & Chiroteuthis imperator & 1.0 & 0.4 & 8.3 & 0.3 \\
\hline 15 & OC & $\begin{array}{l}\text { Japetella diaphana } \\
\text { Total no. inds: } 861 \\
\text { Total wet wt (g): } 478595.1\end{array}$ & 0.7 & 0.0 & 2.4 & $<0.1$ & 15 & $\mathrm{TF}$ & $\begin{array}{l}\text { Lampadena luminosa } \\
\text { Total no. inds: } 98 \\
\text { Total wet wt (g): } 18228.8\end{array}$ & 1.0 & 0.1 & 8.3 & 0.2 \\
\hline
\end{tabular}

respectively. The transition water myctophid fish Diaphus gigas ranked second in both $N(11.9 \%)$ and $F$ $(36.8 \%)$. As a result, \%IRI values did not differ greatly between O. bartramii $(22.3 \%)$ and D. gigas $(13.7 \%)$, indicating that $O$. bartramii contributed more to prey composition by weight, whereas $D$. gigas contributed more in number and frequency of occurrence. Although Pacific lancetfish Alepisaurus ferox ranked second in $W(10.4 \%)$, its $N(0.8 \%)$ and $F(6.6 \%)$ values were much lower than those of G. borealis, O. bartramii, and $D$. gigas. The \%IRIs for A. ferox and other prey species were $<3.0 \%$. These results indicate that $B$. japonica, one of the main prey species during winter and spring, almost disappeared from the stomachs of Xiphias gladius in summer, and was replaced by $G$. borealis and D. gigas.

\section{Transition zone in autumn}

Ommastrephes bartramii was the most common species found in the autumn, with $N$ and $W$ values of 20.4 and $38.0 \%$, respectively, followed by Gonatopsis borealis (13.3 and 13.8\%). These 2 species and Diaphus gigas were commonly found in the stomachs of Xiphias gladius $(F, 33.3-50.0 \%)$. D. gigas was the third most important prey in terms of $N(9.2 \%)$, although $W$ of this species (1.1\%) was much lower than those of $O$. bartramii $(38.0 \%), G$. borealis $(13.8 \%)$, giant squid Onykia robusta $(13.6 \%)$, and ribbonfish Desmodema sp. (13.1\%). As a result, the \%IRIs were $42.0,24.3$, and $11.1 \%$ for $O$. bartramii, $G$. borealis, and D. gigas, respectively. The \%IRIs for other species were $<4.5 \%$. 


\section{Prey size and seasonal changes in SCI}

The size-frequency distribution of Ommastrephes bartramii found in the Xiphias gladius stomachs showed a clear mode between 300 and $450 \mathrm{~mm}$ DML in winter (Fig. 3). In spring, O. bartramii found in the fish stomachs ranged from 80 to $500 \mathrm{~mm}$, and 2 modes were recognized, between 80 and $150 \mathrm{~mm}$ and between 300 and $500 \mathrm{~mm}$. The first mode was between 100 and $300 \mathrm{~mm}$ in summer and between 150 and $350 \mathrm{~mm}$ in autumn. In both winter and spring, the other common prey species, Brama japonica, ranged in size from 300 to $400 \mathrm{~mm}$ SL (Fig. 3). In the transition zone in summer and/or autumn, sizes of Gonatopsis borealis and Diaphus gigas, which were frequently found in $X$. gladius stomachs in these seasons, were mainly 100-250 mm DML and 100-140 mm SL, respectively (Fig. 3). These results, and the aforementioned finding that $O$. bartramii $>300 \mathrm{~mm}$ were rarely fed on by $X$. gladius during summer and autumn, indicate that the prey size spectrum of $X$. gladius shifts to a smaller range from spring to summer (80-500 mm vs. 100-300 mm). These results also indicate that the main prey size of $X$. gladius was 80 to $500 \mathrm{~mm}$ in this study area.

The mean SCI was significantly larger in winter and spring than in summer and autumn (1.74 vs. 0.84-1.05\%, Mann-Whitney $U$-test with Bonferroni correction factor: $\mathrm{p}<0.05$; Table 4 ), suggesting that feeding conditions for Xiphias gladius were better in the subtropical region in winter and spring than they were in the transition zone in summer and autumn.

\section{DISCUSSION}

\section{Differences in feeding conditions between subtropical and transition regions}

The main distribution area of Xiphias gladius in each season approximately corresponded to the $17-19^{\circ} \mathrm{C}$ SST isotherm line throughout the year (Polovina et al. 2000, Seki et al. 2002, Baker et al. 2007). This SST (a) Ommastrephes bartramii
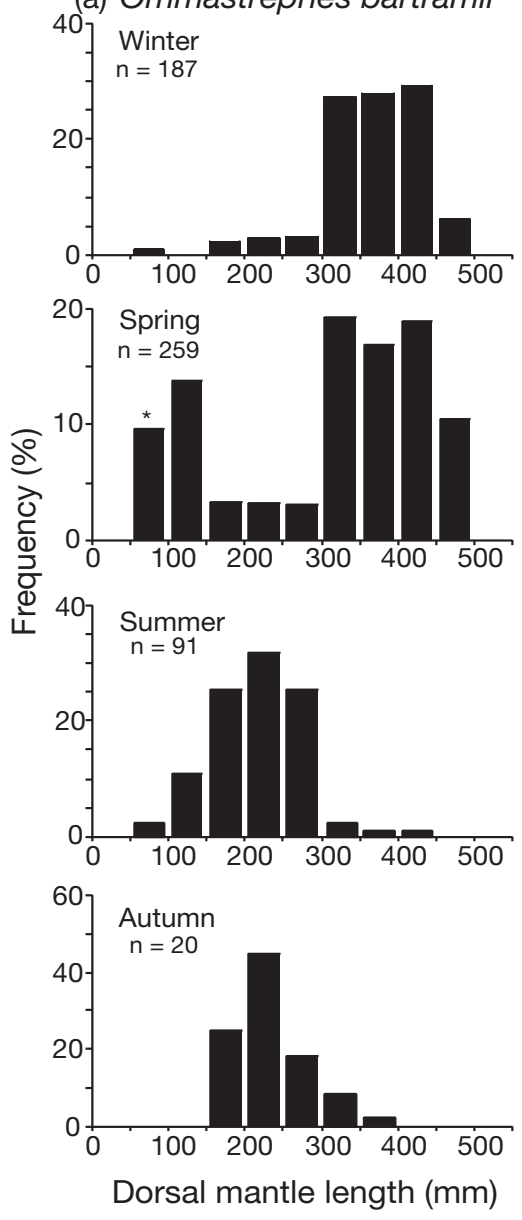

(b) Brama japonica
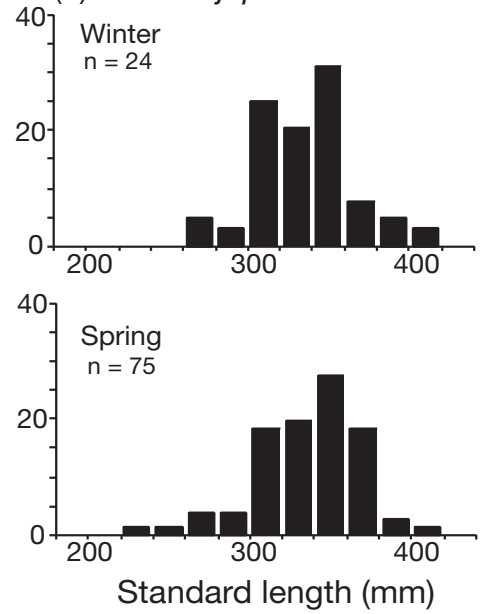

(c) Gonatopsis borealis
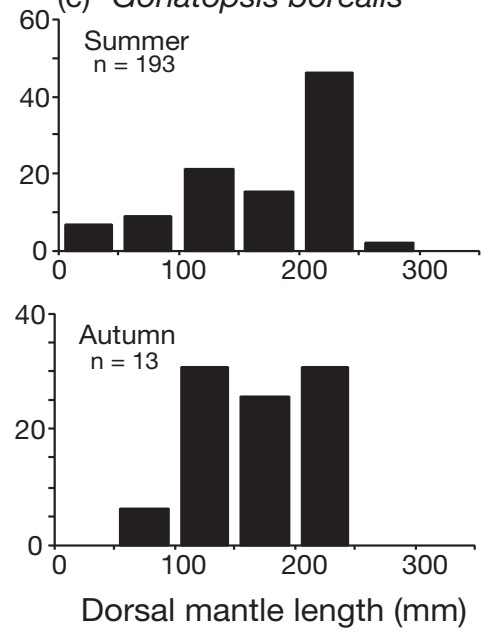

(d) Diaphus gigas

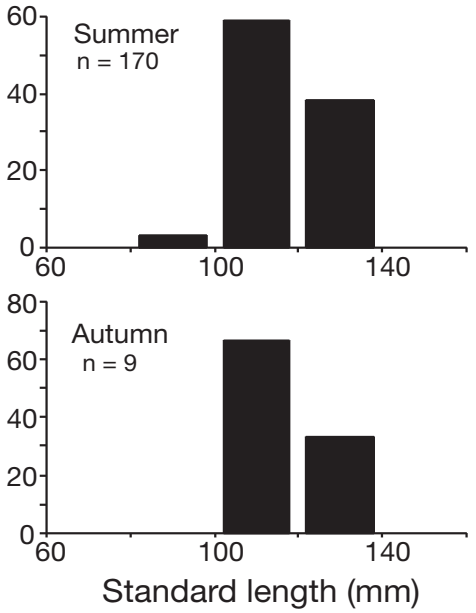

Fig. 3. Sizes of the major squid and fish prey species of Xiphias gladius in subtropical and transition waters of the western North Pacific. Sizes are dorsal mantle length for squids and standard length for fishes. $\mathrm{n}$ : number of individuals found in the swordfish stomachs; *: the smallest size was $80 \mathrm{~mm}$ 
Table 4. Xiphias gladius. Seasonal changes in the stomach content index $(\mathrm{SCI}, \%)$ in the western North Pacific

\begin{tabular}{|lcccc|}
\hline \multirow{2}{*}{ Season } & Average & SD & \multicolumn{2}{c|}{$\begin{array}{c}\text { Range } \\
\end{array}$} \\
& & & Minimum & Maximum \\
\hline Winter & 1.74 & 1.50 & 0.01 & 7.13 \\
Spring & 1.74 & 1.75 & 0 & 10.80 \\
Summer & 1.05 & 1.02 & 0 & 5.14 \\
Autumn & 0.84 & 0.86 & 0.05 & 0.12 \\
\hline
\end{tabular}

range corresponded well with the SST range of $X$. gladius captured in this study. Furthermore, the sampling positions in each season well corresponded to the habitat of $X$. gladius estimated from archival tag data (Takahashi et al. 2003). These facts suggest that the present samples were taken in the main habitat of $X$. gladius during each season. During winter and spring, these SST areas are mainly located in the subtropical frontal zone (Seki et al. 2002), which, due to its high productivity, is a foraging region for major large pelagic nekton including Brama japonica and the winter-spring cohort of Ommastrephes bartramii before reproduction (Seki \& Bigelow 1993, Seki et al. 2002, Young \& Hirota available at: www.soest.hawaii.edu/ PFRP/pdf/young99.pdf). Therefore, the main distribution area of $X$. gladius in winter may be associated with a food-rich habitat (Fig. 4).

In contrast, the prey environment for Xiphias gladius could be poor in summer and autumn in their main habitat because average SCI values of this species were significantly lower in these seasons than in winter and spring. Previous data indicating that the average BW excluding internal organs of $X$. gladius of 1500 and $2000 \mathrm{~mm}$ EFL collected in this study area is 1.18 to 1.27 times heavier in winter and spring than in summer and autumn (K. Yokawa unpubl. data) might support this view. However, the main habitat of $X$. gladius in each season also corresponds with the transition zone chlorophyll front (TZCF), which migrates into the transition region close to the subarctic boundary from the subtropical frontal zone during spring and summer (Polovina et al. 2000, 2001, Bograd et al. 2004, Baker et al. 2007; Fig. 4). The TZCF is a zone of surface convergence where cool surface waters from the north, containing high levels of chlorophyll $a$, sink beneath warm, oligotrophic waters to the south; this indicates that the region to the north of the TZCF is a productive area (Polovina et al. 2000, 2001, Baker et al. 2007). According to Polovina et al. (2001), albacore tuna Thunnus alalunga also exploit the TZCF as a migration route and as a forage habitat from spring to summer. In the western North Pacific during spring and summer, $T$. alalunga measuring 489 to $762 \mathrm{~mm}$ in fork length predated heavily on juvenile Japanese anchovy Engraulis japonicus (20 to $80 \mathrm{~mm} \mathrm{SL}$ ), which were mainly distributed around the TZCF area, suggesting an enhanced feeding regime for this predator (Watanabe et al. 2004, H. Watanabe unpubl. data). This information and our results might indicate that in terms of summer prey availability, the productive TZCF region is favorable for albacore, which mainly consume small prey $(<80 \mathrm{~mm})$, but unfavorable for $X$. gladius, which seem to prefer larger prey (>80 mm). It appears that $X$. gladius could not adequately utilize the productivity of the TZCF in summer, because many large-sized epipelagic nekton, including the autumn cohorts of Ommastrephes bartramii and Brama japonica, forage in the subarctic region and/or transitional domain north of the subarctic boundary during this time of the year. This probably causes a shift in the size spectrum of prey in the TZCF to a smaller range from spring to summer (Pearcy et al. 1993, 1996, Ichii et al. 2004; Fig. 3). Therefore, the decline in the feeding regime of $X$. gladius from spring to summer is not caused by seasonal changes in productivity in their main habitat, but may be explained by the difference in the size spectrum of potential prey species between these seasons. However, from a trophic standpoint, in summer and autumn the transition zone may be favorable over the subtropical region for $X$. gladius, because the latter area is an oligotrophic region where the flux of nutrients into the euphotic zone is among the lowest of any oceanic environment in these seasons, whereas the former area is more productive (Gjøsaeter \& Kawaguchi 1980, Cullen 1982, Sassa et al. 2002, Ichii et al. 2009).

Although the prey environment is more favorable in the subarctic region than it is in the transition zone in summer (Gjøsaeter \& Kawaguchi 1980, Sassa et al. 2002, Ichii et al. 2004), Xiphias gladius rarely migrate into the subarctic region (Polovina et al. 2000, Takahashi et al. 2003). This is probably due to the low temperature field in the subarctic region, because $X$. gladius are mainly distributed in the mesopelagic zone at $3-6^{\circ} \mathrm{C}$ in the daytime and migrate up to the epipelagic zone at $17-27^{\circ} \mathrm{C}$ at night (Matsumoto et al. 2003, Takahashi et al. 2003, Yokawa 2004), and the water temperatures of the subarctic region, in the both meso- and epipelagic zones, are generally lower than they are in the transition region (approximately less than $4^{\circ} \mathrm{C}$ and $15^{\circ} \mathrm{C}$, respectively; Kawai 1972). Therefore, the summertime northward migration of $X$. gladius is believed to be a feeding migration within their optimal habitat temperature range.

\section{Feeding habits related to northward migration}

Ommastrephes bartramii is among the dominant large pelagic squid in the subtropical and temperate 

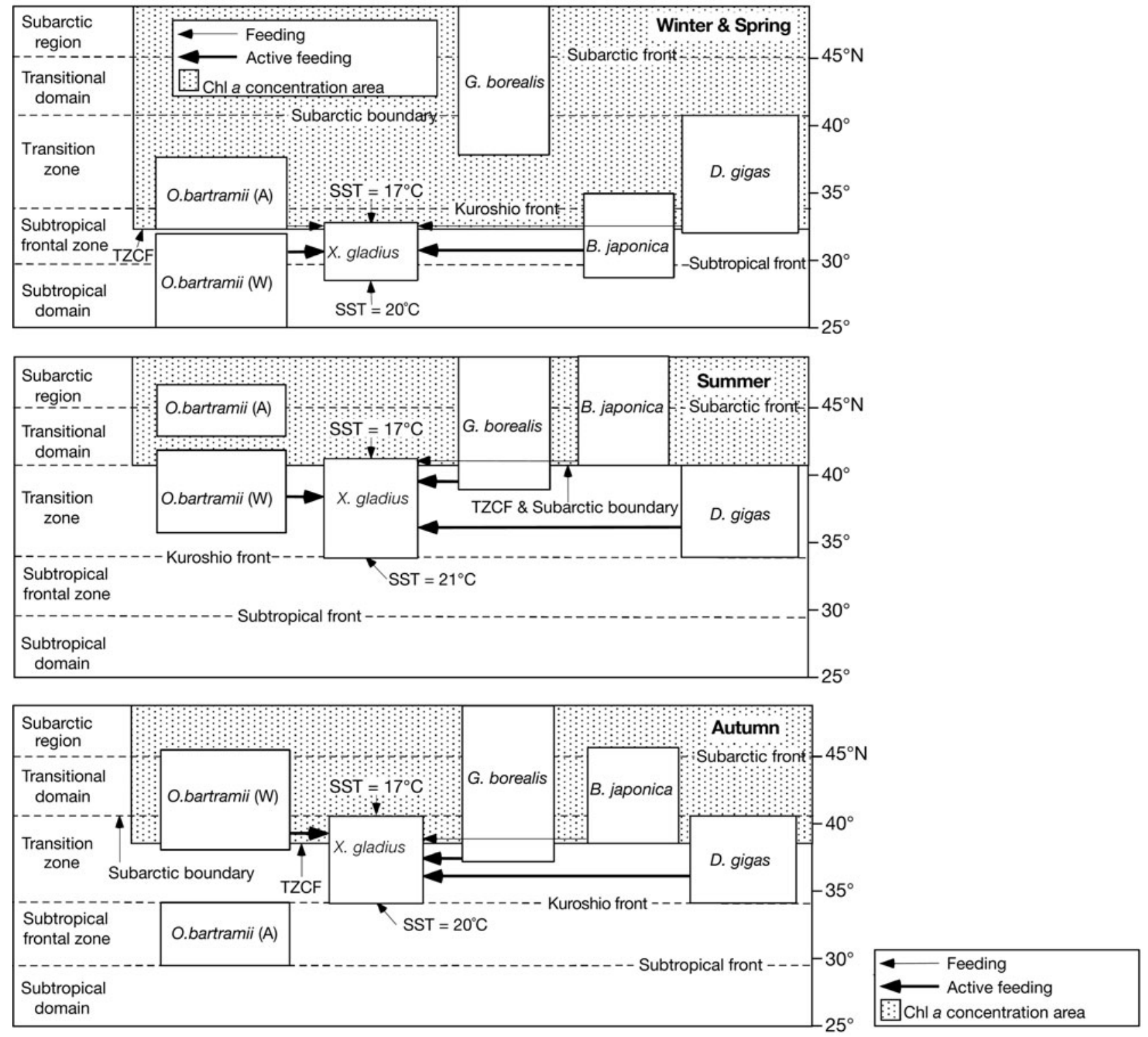

Fig. 4. Predator-prey relationships and seasonal south-north migration patterns of Xiphias gladius and its prey species in subtropical and transition waters of the western North Pacific. Full species names of prey are given in Table 2. A: autumn cohort; W: winter-spring cohort; TZCF: transition zone chlorophyll front

waters of the North Pacific, and its population is composed of the autumn and winter-spring cohorts (Roper et al. 1984, Murata 1990, Murata \& Hayase 1993, Seki 1993, Yatsu et al. 1997). Previous reports on the sizefrequency distribution of $O$. bartramii in each season (Murata \& Hayase 1993, Chen \& Chiu 2003) suggest that most of the individuals found in Xiphias gladius stomachs came from the winter-spring cohort; i.e. $X$. gladius fed on the spawning population of the cohort during winter and spring ( $>300 \mathrm{~mm}$ DML) and on newly recruited individuals of the cohort from spring to autumn $(<200 \mathrm{~mm}$ DML in spring, $<350 \mathrm{~mm}$ DML in summer, and 150-400 mm DML in autumn). The squid found in the stomachs of $X$. gladius, measuring approximately 200-300 mm DML in spring and $>350 \mathrm{~mm}$ DML in summer and autumn, were possibly members of the autumn cohort (Murata \& Hayase 1993). However, their abundance was much lower than that of the winter-spring cohort (see Fig. 3). Previous information of seasonal south-north migration patterns of the 2 cohorts strongly suggests that the predator-prey relationship between $X$. gladius and the winter-spring cohort of $O$. bartramii is maintained almost throughout the year, because their seasonal 
south-north migration patterns are spatiotemporally similar to each other (Fig. 4, Ichii et al. 2009, Young \& Hirota available at: www.soest.hawaii.edu/PFRP/pdf/ young99.pdf). Conversely, X. gladius rarely fed on the autumn $O$. bartramii cohort, because their distributions are almost separate in each season (Yatsu et al. 1997, Ichii et al. 2009, Fig. 4).

Brama japonica was frequently predated upon by Xiphias gladius in the subtropical frontal zone during winter and spring, but almost disappeared from $X$. gladius stomachs in summer and autumn. This corresponds well with the fact that $B$. japonica migrates into the transitional domain and subarctic region in summer (Shimazaki \& Nakamura 1981, Pearcy et al. 1993, Ichii et al. 2004; Fig. 4). Diaphus gigas and Gonatopsis borealis are typical subarctic or transition water species and rarely occur in subtropical waters (Wisner 1976, Naito et al. 1977, Kawaguchi \& Shimizu 1978, Kubodera et al. 1983, Kubodera \& Jefferts 1984). Our results showed that $X$. gladius frequently fed on these species only in the transition zone during summer and/or autumn, reflecting the zoogeographical distribution patterns of these prey species (Fig. 4).

\section{Feeding habits related to diel vertical migrations}

Fig. 5 shows the diel vertical migration patterns of Xiphias gladius and their prey, as well as possible predator-prey relationships estimated from stomach content analyses. Generally, X. gladius are distributed in the 300-600 $\mathrm{m}$ layer during the day and migrate to the 0-100 m layer at night (Carey \& Robinson 1981, Matsumoto et al. 2003, Takahashi et al. 2003, Yokawa 2004). Among the main X. gladius prey in each season, Brama japonica is frequently captured in the epipelagic zone at depths shallower than $100 \mathrm{~m}$ during both day and night (Shimazaki \& Nakamura 1981, Ichii et al. 2004, H. Watanabe unpubl. data). The distribution depth of B. japonica overlaps with that of X. gladius during the night in the epipelagic zone (Fig. 5). In the continental shelf region, $X$. gladius is distributed near the bottom and frequently feeds on demersal fish during the day (Carey \& Robinson 1981, HernandezGarcia 1995). In the present study, the Histioteuthidae and Chiroteuthidae squid fed on by $X$. gladius are nonmigratory, and throughout the day are mainly distributed in the mesopelagic zone (Watanabe et al. 2006; see Table 2). These results might indicate that $X$. glad-

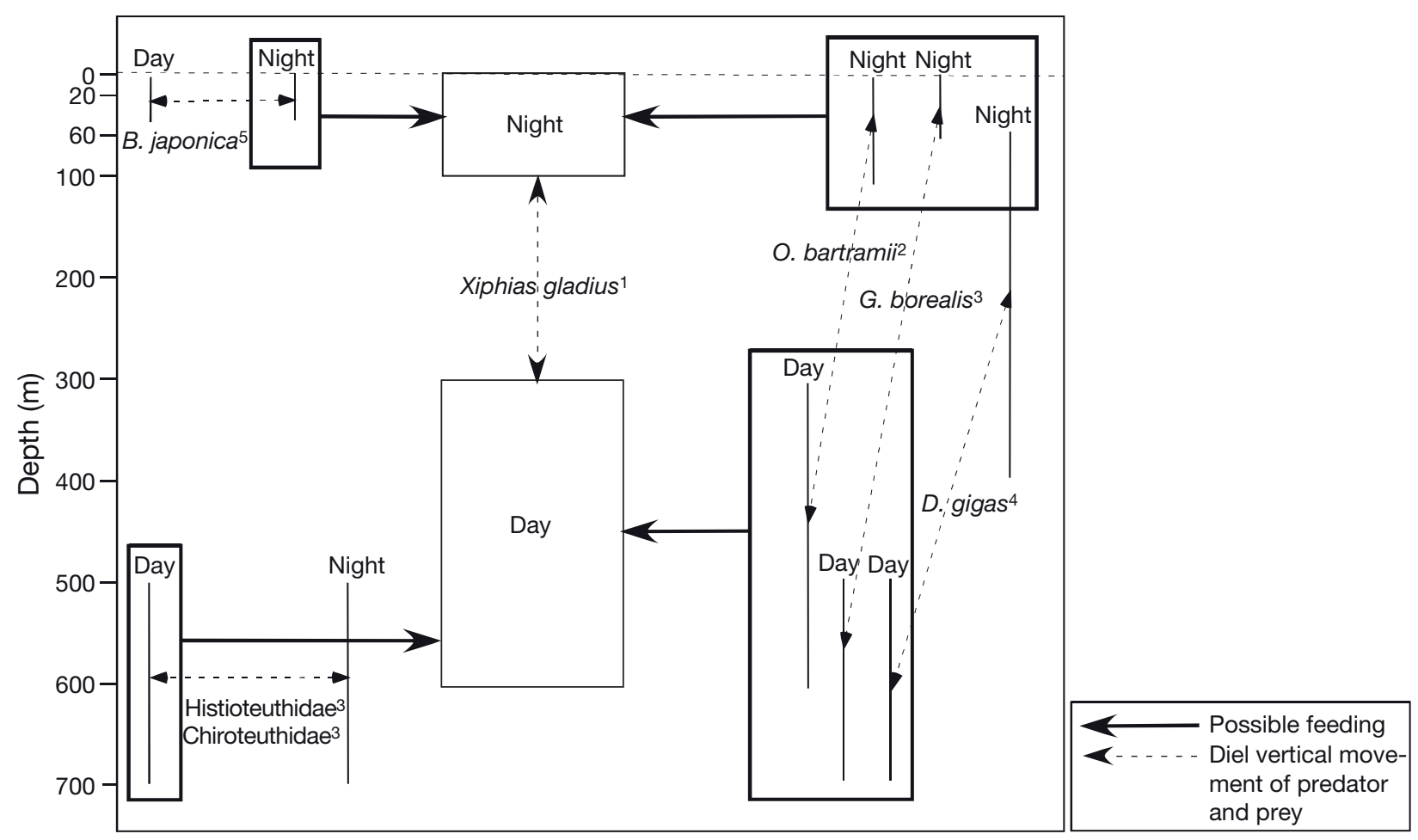

Fig. 5. Predator-prey relationships and diel vertical migration patterns of Xiphias gladius, major prey species, and 2 typical mesopelagic squid prey (Histioteuthidae and Chiroteuthidae) in subtropical and transition waters of the western North Pacific. Full species names of prey are given in Table 2. Data of day-night vertical distribution of each species are cited from ${ }^{1}$ Takahashi et al. (2003), ${ }^{2}$ Tanaka (2001) and Nakamura (1993), ${ }^{3}$ Watanabe et al. (2006), ${ }^{4}$ Watanabe et al. (1999), and ${ }^{5} \mathrm{H}$. Watanabe (unpubl. data) 
ius possibly feeds in the mesopelagic zone during the day in this study area. Therefore, it is possible that $X$. gladius feeds on prey that migrate vertically, such as Ommastrephes bartramii, Gonatopsis borealis, and Diaphus gigas, during both day and night, because their diel vertical migration patterns overlap each other (Nakamura 1993, Watanabe et al. 1999, 2006, Tanaka 2001; Fig. 5). Since these vertical migratory species are abundant in the transition waters of the western North Pacific (Kubodera et al. 1983, Watanabe et al. 1999, 2006, Ichii et al. 2004), their continuous availability would be beneficial to $X$. gladius.

Acknowledgements. We thank T. Ichii, M. Kiyota, M. Sakai, T. Shimose, S. Minamikawa, and Y. Kanaji of the National Research Institute of Far Sea Fisheries; K. Hoshino of the Seikai National Fisheries Research Institute; and G. Shinohara of the National Science Museum for their assistance during the course of this study. D. Inagake of the National Research Institute of Fisheries Science shared his knowledge of the oceanography in the subtropical region. This study was supported by a grant from the Fisheries Agency of Japan.

\section{LITERATURE CITED}

Baker JD, Polovina JJ, Howell EA (2007) Effect of variable oceanic productivity on the survival of an upper trophic predator, the Hawaiian monk seal Monachus schauinslandi. Mar Ecol Prog Ser 346:277-283

Bograd SJ, Foley DG, Schwing FB, Wilson C and others (2004) On the seasonal and interannual migration of the transition zone chlorophyll front. Geophys Res Lett 31:L17204. doi:10.1029/2004GL020637

Carey FG, Robinson BH (1981) Daily patterns in the activities of swordfish, Xiphias gladius, observed by acoustic telemetry. Fish Bull 79:277-292

Chen C, Chiu T (2003) Variation of life history parameters in two geographical groups of the neon flying squid, Ommastrephes bartramii, from the North Pacific. Fish Res 63:349-366

Clarke MR (1986) A handbook for the identification of cephalopod beaks. Clarendon Press, Oxford

Cortes E (1997) A critical review of methods of studying fish feeding based on analysis of stomach contents: application to elasmobranch fishes. Can J Fish Aquat Sci 54:726-738

Cullen JJ (1982) The deep chlorophyll maximum: comparing vertical profiles of chlorophyll a. Can J Fish Aquat Sci 39: 791-803

Favorite F, Dodimead AJ, Nasu K (1976) Oceanography of the subarctic Pacific region, 1960-71. Bull Int N Pac Fish Comm 33:1-187

Garcia SM, Zerbi A (2003) Ecosystem approach to fisheries: issues, terminology, principles, institutional foundations, implementation and outlook. FAO Fish Tech Pap 443:1-71

Gjøsaeter J, Kawaguchi K (1980) A review of the world resources of mesopelagic fish. FAO Fish Tech Pap 193: $1-151$

Hernandez-Garcia V (1995) The diet of the swordfish, Xiphias gladius Linnaeus, 1758, in the central east Atlantic, with emphasis on the role of cephalopods. Fish Bull 93:403-411

Ichii T, Mahapatra K, Sakai M, Inagake D, Okada Y (2004) Differing body size between the autumn and the winter- spring cohorts of neon flying squid (Ommastrephes bartramii) related to the oceanographic regime in the North Pacific: a hypothesis. Fish Oceanogr 13:295-309

Ichii T, Mahapatra K, Sakai M, Okada Y (2009) Life history differences between seasonal cohorts of the neon flying squid associated with the oceanographic regime in the North Pacific. Mar Ecol Prog Ser 378:1-11

Kawaguchi K, Shimizu H (1978) Taxonomy and distribution of the lanternfishes, genus Diaphus (Pisces, Myctophidae) in the western Pacific, eastern Indian Oceans and the southeast Asian Seas. Bull Ocean Res Inst Univ Tokyo 10:1-145

Kawai H (1972) Hydrography of the Kuroshio and the Oyashio. In: Iwashita M, Komaki Y, Hoshino T, Horibe S, Masuzawa J (eds) Physical oceanography II, Kaiyokagaku Kiso Koza (Fundamental Lecture of Oceanography). Tokai University Press, Tokyo, p 129-320 (in Japanese)

Kubodera T (1982) Ecological studies of pelagic squids in the subarctic Pacific region. PhD thesis, Hokkaido University, Hakodate (in Japanese)

Kubodera T, Furuhashi M (1987) A manual for identification of myctophid fishes and squids in the stomach contents. Report on the development of ecosystem modeling in the northern North Pacific, supplement. Fisheries Agency of Japan, Tokyo (in Japanese)

Kubodera T, Jefferts K (1984) Distribution and abundance of the early life stages of squid, primarily Gonatidae (Cephalopoda, Oegopsida) in the northern North Pacific. Part 2. Bull Natl Sci Mus Ser A (Zool) 10:165-193

Kubodera T, Shimazaki K (1989) Cephalopods from the stomach contents of the pomfret (Brama japonica Hilgendorf) caught in surface gillnets in the northern North Pacific. J Cephalopod Biol 1:71-83

Kubodera T, Pearcy WG, Murakami K, Kobayashi T, Nakata J, Mishima S (1983) Distribution and abundance of squids caught in surface gillnets in the subarctic Pacific, 1977-1981. Mem Fac Fish Hokkaido Univ 39:1-49

Markaida U, Sosa-Nishizaki O (1998) Food and feeding habits of swordfish, Xiphias gladius L., off western Baja California. NOAA Tech Rep NMFS 142:245-259

Matsumoto T, Saito H, Miyabe N (2003) Report of observer program for Japanese tuna longline fishery in the Atlantic Ocean from September 2001 to March 2002. Col Vol Sci Pap ICCAT 55:1679-1718

Moreira F (1990) Food of the swordfish, Xiphias gladius Linnaeus, 1758, off the Portuguese coast. J Fish Biol 36: $623-624$

Moteki M, Arai M, Tsuchiya K, Okamoto H (2001) Composition of piscine prey in the diet of large pelagic fish in the eastern tropical Pacific Ocean. Fish Sci 67:1063-1074

Murata M (1990) Oceanic resources of squids. Mar Behav Physiol 18:19-71

Murata M, Hayase S (1993) Life history and biological information on flying squid (Ommastrephes bartramii) in the North Pacific Ocean. Bulletin INPFC 53:147-182

Naito M, Murakami K, Kobayashi T (1977) Distribution and migration of oceanic squids (Ommastrephes bartramii, Onychoteuthis borealijaponica, Berryteuthis magister and Gonatopsis borealis) in the western subarctic Pacific region. Spec Vol Res Inst N Pac Fish Hokkaido Univ Fac Fish 321-337 (in Japanese with English abstract)

Nakamura I (1985) FAO species catalogue Vol 5: billfishes of the world. An annotated and illustrated catalogue of marlins, sailfish, spearfishes and swordfishes known to date. FAO Fish Synop 125:1-65

Nakamura Y (1993) Vertical and horizontal movements of mature females of Ommastrephes bartramii observed by ultrasonic telemetry. In: Okutani T, O'Dor RK, Kubodera T 
(eds) Recent advances in fisheries biology. Tokai University Press, Tokyo, p 331-336

Ohizumi H, Watanabe H, Moku M, Kawahara S (2001) Species identification for otoliths of myctophid fishes in the western North Pacific. Aquabiology 137:626-637 (in Japanese with English abstract)

Pearcy WG (1991) Biology of the transition region. NOAA Tech Rep NMFS 105:39-55

Pearcy WG, Fisher JP, Yoklavich MM (1993) Biology of the Pacific pomfret (Brama japonica) in the North Pacific Ocean. Can J Fish Aquat Sci 50:2608-2625

Pearcy WG, Fisher JP, Anma G, Meguro T (1996) Species associations of epipelagic nekton of the North Pacific Ocean, 1978-1993. Fish Oceanogr 5:1-20

Pinkas L, Oliphant MS, Iverson ILK (1971) Food habits of albacore, bluefin tuna, and bonito in California waters. Calif Dept Fish Game Fish Bull 152:1-105

Polovina JJ, Kobayashi DR, Parker DM, Seki MP, Balazs GH (2000) Turtles on the edge: movement of loggerhead turtles (Caretta caretta) along oceanic fronts spanning longline fishing grounds in the central North Pacific, 1997-1998. Fish Oceanogr 9:71-82

Polovina JJ, Howell E, Kobayashi DR, Seki MP (2001) The transition zone chlorophyll front, a dynamic, global feature defining migration and forage habitat for marine resources. Prog Oceanogr 9:71-82

Roden GI (1991) Subarctic-subtropical transition zone of the North Pacific: large-scale aspects and mesoscale structure. NOAA Tech Rep NMFS 105:1-38

Roper CFE, Sweeney MJ, Nauen CE (1984) FAO species catalogue. Vol 3: Cephalopods of the world. An annotated and illustrated catalogue of species of interest to fisheries. FAO Fish Synop 125:1-277

Sakagawa GT, Bell RR (1980) Swordfish, Xiphias gladius. In: Shomura RS (ed) Summary report of the billfish stock assessment workshop, Pacific resources. Honolulu Laboratory, NOAA, NMFS, SWFC, December 5-14, 1977 , Hawaii. Tech Memo 5: 40-50

Sassa C, Kawaguchi K, Kinoshita T, Watanabe C (2002) Assemblages of vertical migratory mesopelagic fish in the transitional region of the western North Pacific. Fish Oceanogr 11:193-204

Scott WB, Tibbo SN (1968) Food and feeding habits of swordfish, Xiphias gladius, in the western North Atlantic. J Fish Res Board Can 25:903-919

Seki MP (1993) The role of neon flying squid, Ommastrephes bartramii, in the North Pacific food web. In: Ito J, Shaw W, Burgner RL (eds) INPFC symposium on biology, distribution, and stock assessment of species caught in the high sea driftnet fisheries in the North Pacific Ocean, Vancouver, Canada. Bull Int N Pac Fish Comm 53:207-215

Seki MP, Bigelow KA (1993) Aspects of the life history and ecology of the Pacific pomfret Brama japonica during winter occupation of the subtropical frontal zone. In: Ito J, Shaw W, Burgner RL (eds) INPFC symposium on biology, distribution, and stock assessment of species caught in

Editorial responsibility: Kenneth Sherman,

Narragansett, Rhode Island, USA the high sea driftnet fisheries in the North Pacific Ocean, Vancouver, Canada. Bull Int N Pac Fish Comm 53: 273-283

Seki MP, Polovina JJ, Kobayashi DR, Bidigare RR, Mitchum GT (2002) An oceanographic characterization of swordfish (Xiphias gladius) longline fishing grounds in the springtime subtrophical North Pacific. Fish Oceanogr 11:251-266

Shimazaki K, Nakamura S (1981) Ecological studies of the pomfret (Brama japonica Hilgendorf). 1. The seasonal distribution pattern and ecological considerations. Spec Vol Res Inst N Pac Fish Hokkaido Univ Fac Fish 91-103 (in Japanese with English abstract)

Smale MJ, Watson G, Hecht T (1995) Otolith atlas of southern African marine fishes. Ichthyological monographs, No. 1. JLB Smith Institute of Ichthyology, Grahamstown

Stillwell CE, Kohler NE (1985) Food and feeding ecology of the swordfish Xiphias gladius in the western North Atlantic Ocean with estimates of daily ration. Mar Ecol Prog Ser 22:239-247

Sun C, Wang S, Yeh S (2002) Age and growth of the swordfish (Xiphias gladius L.) in the waters around Taiwan determined from anal-fin rays. Fish Bull 100:822-835

- Takahashi M, Okamura H, Yokawa K, Okazaki M (2003) Swimming behavior and migration of a swordfish recorded by an archival tag. Mar Freshw Res 54:527-534

Tanaka H (2001) Tracking the neon flying squid by the biotelemetry system in the central North Pacific Ocean. Aquabiology. (in Japanese with English abstract)

Toll RB, Hess SC (1981) Cephalopods in the diet of the swordfish, Xiphias gladius, from the Florida Straits. Fish Bull 79: 765-774

> Watanabe H, Moku M, Kawaguchi K, Ishimaru K, Ohno A (1999) Diel vertical migration of myctophid fishes (family Myctophidae) in the transitional waters of the western North Pacific. Fish Oceanogr 8:115-127

> Watanabe H, Kubodera T, Masuda S, Kawahara S (2004) Feeding habits of albacore Thunnus alalunga in the transition region of the central North Pacific. Fish Sci 70: 573-579

Watanabe H, Kubodera T, Moku M, Kawaguchi K (2006) Diel vertical migration of squid in the warm core ring and cold water masses in the transition region of the western North Pacific. Mar Ecol Prog Ser 315:187-197

Wisner RL (1976) The taxonomy and distribution of lanternfishes (family Myctophidae) of the eastern Pacific Ocean. Bay St Louis, Mississippi, Navy Ocean Research and Development Activity Rep No. 3

World Summit on Sustainable Development (2002) Plan of implementation. International Union for Conservation of Nature, Johanesburg

Yatsu A, Midorikawa S, Shimada T, Uozumi Y (1997) Age and growth of the neon flying squid, Ommastrephes bartramii, in the North Pacific. Fish Res 29:257-270

Yokawa K (2004) Swordfish in the western North Pacific. In: The current status of international fishery stocks. Fisheries Agency of Japan, Tokyo, p 191-196 (in Japanese)

Submitted: June 19, 2009; Accepted: September 18, 2009

Proofs received from author(s): November 19, 2009 